\title{
Nicholas GEORGESCU-ROEgEN AND DEGROWTH
}

\author{
Antoine MISSEMER ${ }^{*}$
}

\section{Full reference:}

MiSSEMER, Antoine. 2017. "Nicholas Georgescu-Roegen and Degrowth". European Journal of the History of Economic Thought, vol. 24(3), p. 493-506.

[http://dx.doi.org/10.1080/09672567.2016.1189945]

The pagination of the published version is indicated in the margin.

\begin{abstract}
As a peculiar economist of the twentieth century, Nicholas Georgescu-Roegen gave birth to many controversies. Since the 1970s, in particular in the French language literature, Georgescu-Roegen's ecological claim has often been considered as a promotion of degrowth. In this paper, I challenge this usual interpretation. I conclude that Georgescu-Roegen might be a source of inspiration for degrowth defenders only in a very narrow sense. A cautious reading of his bioeconomic paradigm shows that Georgescu-Roegen's stance was different from the growth/degrowth debate, and might be more accurately linked with an "agrowth" option.
\end{abstract}

Keywords: history of economic thought, Georgescu-Roegen, degrowth, bioeconomics, agrowth

\footnotetext{
* [In 2017] CNRS, CIRED - Centre international de recherche sur l'environnement et le développement (UMR 8568 CNRS/ENPC/EHESS/AgroParisTech/CIRAD), 45 bis avenue de la Belle Gabrielle, 94736 Nogent-sur-Marne Cedex, France. E-mail: missemer@centre-cired.fr
} 


\section{Introduction}

Did Nicholas Georgescu-Roegen defend degrowth? This question may be surprising, since it seems to have been answered for a long time: of course he did. If the reader is familiar with the French language literature, he will be surprised even more, since the most famous French language book of Georgescu-Roegen is entitled La Décroissance (Sang de la terre, 2006, $1^{\text {st }}$ ed. 1979). Nevertheless, as I show in the following lines, this question deserves interest. The degrowth interpretation of GeorgescuRoegen's bioeconomics is not single, perhaps neither the most accurate one.

Nicholas Georgescu-Roegen has been the subject of revival studies for a few years, in history of economic thought, on the one hand (Bonaiuti 2011, Bobulescu 2012, 2013, 2015, Missemer 2013), and in environmental and ecological economics, on the other hand (Farrell and Mayumi 2009, Fisk 2011, Herrmann-Pillath 2011, Cleveland and Morris 2014). This renewal might be explained not only by the accuracy of Georgescu-Roegen's works in the context of the current global warming and resources scarcity discussions (see Grinevald 2007), but also, and first of all, by a recognition of his bioeconomic project as a wealthy and promising research programme.

Built around a consistent frame, GeorgescuRoegen's bioeconomics consists in redefining the economic sphere, both as a discipline (economics) and as a set of practices (economy), in relationship with its bio-physical environment. This Lotkian-vernadskian ${ }^{1}$ framework (Grinevald 1990, Bobulescu 2015) leads Georgescu-Roegen to elaborate a new epistemology based on thermodynamics and biology. The economy is a subsystem of the global environment. Producing, consuming, and investing are activities that depend on the natural environment. This environment raises constraints, in terms of resources scarcity and ecosystem balances. Yet, as a matter of fact, producers, consumers, and investors ignore those

\footnotetext{
${ }^{1}$ Alfred Lotka played a great part in Georgescu-Roegen's intellectual background, with his definition of biological evolution. Vladimir Vernadsky coined the concept of biosphere. Even if his influence on Georgescu-Roegen has been indirect, it keeps interest.
}

constraints, as economists do when they study the economic realm. In their economic theories and practices, human beings have to take into account the bio-physical constraints of their environment. Otherwise, they will only wait for their auto-destruction.

This pessimistic viewpoint on economic dynamics drove a large part of scholars to consider Georgescu-Roegen's bioeconomics as a radical perspective. So radical that it could be considered as a pioneering work for deep ecology and degrowth. Degrowth is a young concept, progressively used in the 1990s and that has been theorised for a few years, as the Ecological Economics' 2009 symposium issue testifies. The current degrowth movement is varied, with many different contributors that sometimes oppose one another. Paul Ariès, Mauro Bonaiuti, Giorgos Kallis, Serge Latouche, and Joan Martinez-Alier, to cite only some authors, do not share the same idea of degrowth. And there are many ways of defining what degrowth should be (for an overview, see van den Bergh 2011, pp. 882-5).

Georgescu-Roegen is clearly a source of inspiration for most degrowth partisans, as Bonaiuti expresses himself $(2011,2012)$. It would be unfair to contest this historical influence, since his radical perspective and his criticism of industrial production echo some claims of the degrowth movement. But does that mean that Georgescu-Roegen himself was a defender of degrowth? Many commentators say yes. ${ }^{2}$ My point is to challenge this idea, and to measure the accuracy of the degrowth interpretation of bioeconomics. To focus on a clear conception of degrowth, I define it as the decrease of aggregate production, measured, for instance, by the GDP. Some degrowth partisans would not accept such a definition. But it is the most typical one, often shared, ${ }^{3}$ and "the most logical interpretation and useful one in the sense that it is likely to be understood as such by most economists, politicians and the general public"

\footnotetext{
${ }^{2}$ See for instance, Bayon et al. (2012), Bobulescu (2013), Bürgenmeier (2008), Durand (2008), Grinevald (1992, 2008), Levallois (2010), Petit (1997), and Vivien (1994, 2005a, 2005b).

${ }^{3}$ Kallis et al. (2012, p. 175) state that "degrowth entails [...] GDP decline, [even if it] is not reducible to [it]". See also Paris Décroissance (2008, p. 317).
} 
(van den Bergh 2011, p. 882).

To develop my argument, I present in Section 2 Georgescu-Roegen's bioeconomics through its epistemological foundations and analytical novelties. In Section 3, I look at the arguments that support a degrowth interpretation of Georgescu-Roegen's works: practical measures that curb industrial production, episodic quotations. In Section 4, enhancing the internal coherence of bioeconomics, I challenge this interpretation and I show the inconsistency of degrowth with some bioeconomic basics. Finally, in Section 5, I make some concluding remarks, underlying the fact that GeorgescuRoegen's project is disconnected from the growth/degrowth debate, and could be more accurately linked with an "agrowth" option, as Jeroen C. J. M. van den Bergh (2011) defines it.

\section{Bioeconomics}

As it has been described elsewhere (Missemer 2013), Georgescu-Roegen's proposal to renew economics is built as a threedimensional coherent paradigm, with a first set of epistemological foundations, a second set of analytical tools, and a third set of practical measures. The first set relies on a criticism addressed to most economists who make too many references to Newtonian mechanics (Georgescu-Roegen 1971, p. 40). Equilibria, forces, and reversibility are part of a usual rhetoric that drives economists in the wrong way in their understanding of economic phenomena. This is not a matter of scientific ideals, but a problem of realism. Since thermodynamics and evolutionism show that the world does not run according to mere Newtonian laws, and that qualitative change, stochastic evolution, and irreversibility matter, an accurate economic knowledge must take into account these facts and changes (Georgescu-Roegen 1977, p. 267). In other words, it needs to incorporate thermodynamic and biological teachings into its theories and public policy recommendations. Otherwise economics will only be an abstract science, with no link with the economy.

Georgescu-Roegen was not only inspired by Darwin to integrate stochastic changes and evolutionary biology in his paradigm, he also used Alfred Lotka's bio-anthropological works (Georgescu-Roegen 1978, p. 339, 1993, p. 184; see also Bobulescu 2015). In Lotka's view, human beings have, with some other rare species, the specificity to have attained a peculiar stage of their evolution: they not only use endosomatic tools (arms, legs, hands) but also exosomatic tools (saws, pens, motors). As Georgescu-Roegen points out (1983, p. 143, 1993 , p. 185), this change has reached an extreme point, since exosomatic tools multiplied and invaded all the spheres of human action. In a sense, economics is the science that studies the exosomatic stage of evolution. It is an extension of evolutionary biology, and therefore it cannot ignore qualitative changes and irreversibility.

In The Entropy Law and the Economic Process (1971), Georgescu-Roegen crystallises many of his warnings by highlighting the entropy principles needed to be included into economic analysis. There are three main entropy principles in thermodynamics. All of them deal with the potential degradation of useful energy. This inevitable dissipation has dramatic consequences for economic production: insofar the economic realm is a closed system that removes from the Earth useful energy and matter to produce goods and waste, it cannot develop indefinitely without caring about ecological boundaries. As a consequence, production processes must be represented through an accurate framework that takes into account qualitative change, and that do not ignore natural constraints. Refusing the aggregate production function, Georgescu-Roegen proposes (1971, pp. 211-75) his own model, named the fund-flow model. In his view, two kinds of productive agents must be distinguished: funds and flows. While funds cross processes without deterioration, flows are either input-flows (raw materials, intermediate goods) or output-flows (products, waste), but never both (for details, see Maneschi and Zamagni 1997, Vit- tucci Marzetti 2013). Even though funds look like fixed capital (Kurz and Salvadori 2003, p. 494), they are not stocks, as Georgescu-Roegen indicates (1971, p. 226), because they cannot be instantaneously accumulated or decumulated. The idea is to formalise production as sequences of elementary processes that consist of the combination of funds (delivering productive services) and flows 
(both to create products and to maintain funds) inside temporal and spatial analytical boundaries. It enables a new kind of economics of production, in which thermodynamic and biological teachings (natural constraints, entropy, qualitative change) are taking into account.

Georgescu-Roegen's project does not only consist in describing economic processes in an ecological manner, it also aims at proposing actions to conciliate human activities and natural constraints. Distinguishing between feasible and viable technologies, Georgescu-Roegen (1984) sheds light on the limits to technical progress. Many feasible technologies exist, like solar panels, but these technologies are not viable since they rest upon fossil materials (for example, rare earth metals). Coining a fourth law of thermodynamics, Georgescu-Roegen worries about the degradation of matter, besides energy dissipation. ${ }^{4}$ As a consequence, a technology that uses fossil materials cannot be sustainable. It seems that the next radical technological revolution is still far away from now (Georgescu-Roegen 1983, p. 144, 1989, p. 168).

In that framework, what would be a sustainable way of development? To answer this question, Georgescu-Roegen formulates a "bioeconomic programme" (1975, pp. 377-8), also called "ABC bioéconomique" (1978, pp. 367-76). It consists of three sets of measures: a set of technological measures, a set of public policy measures, and a set of ethical measures. On the first range of measures, solar energy needs to be improved to become ecologically viable and to spread over all human activities (Georgescu-Roegen 1978, p. 372). In the same way, intensive agriculture should be replaced by organic agriculture (Georgescu-Roegen 1975, p. 378,1977, p. 270). On the second range, public expenditures need to be reconsidered to be allocated to useful fields (no more military investment), and public regulations must guarantee the durability of commodities and the good use of energy resources, implementing quotas if needed (Georgescu-Roegen 1975, pp. 377-9). Finally, according to GeorgescuRoegen, building a new society implies

\footnotetext{
${ }^{4}$ Georgescu-Roegen has mostly been contested on this fourth law (see Cleveland and Ruth 1997).
}

behavioural novelties. As he states himself, "a new ethics is what the world needs most" (1977, p. 270). This ethical change requires sobriety and a search for "the enjoyment of life" (1975, p. 353) rather than permanent productivity gains (1971, p. 297). In this pacified society using viable solar energy and caring about material limits, economic development might be possible.

To close this short presentation of GeorgescuRoegen's bioeconomic paradigm, it might be useful to highlight its consistency. Its epistemological foundations, through thermodynamics and evolutionary biology, its analytical tools, for instance with the fund-flow model, and its practical measures make sense together. Research and development in viable technologies are the consequence of the awareness that production processes are ecologically bounded, which result itself from thermodynamics and biology teachings. In that sense, Georgescu-Roegen's project calls for a paradigmatic revolution inside and outside economics.

\section{Degrowth inside bioeconomics}

The key idea of Georgescu-Roegen is that the economic sphere is a sub-system of the natural environment. Consequently, economic practices have to obey some immutable laws that cannot be bypassed. As seen upward, the entropy law, which stipulates that the quantity of available energy in a system necessarily tends to decrease, is probably the most important of these laws. Without natural resources, fossil fuel energies and scarce matter, no economic activity is possible. These resources suffer from the entropy law. They will necessarily be more and more scarce in the future, and that could seriously damage the economic dynamics. The natural environment is limited, so are economic activities. Since these activities mainly consist of commodities production based on fossil fuels and fossil raw materials, the question of their expansion raises issues. In that sense, as Miernyk explains (1999, p. 75), bioeconomics and material expansion are incompatible.

Does it mean that Georgescu-Roegen defended degrowth? One might be tempted to think so. In the fund-flow model, the economics 
of production is shaped as a succession of elementary processes limited by their own spatial, temporal, and, therefore, ecological boundaries. Since no current economic process can develop without material resources, and considering the fact that these resources are limited in quantity because of entropy, it can be shown that some elementary processes will come to an end, and that this will cut the production chain. Yet that does not transform degrowth in a voluntary project, but it makes degrowth necessarily happen if there is no change in the way of producing and consuming goods and services.

In the bioeconomic programme, some of the ethical measures listed above look like degrowth measures. By promoting temperance and frugality for human beings, Georgescu-Roegen seems to lay the foundations for "voluntary simplicity" as it is held by some degrowth partisans (see Ariès 2010). If energy and material consumption decreases, aggregate production might decrease and GeorgescuRoegen's claim could be seen as a degrowth claim. On another point, namely population, bioeconomics also meets degrowth. Because organic agriculture must replace intensive agriculture, food production will probably decrease. The world population will have to adapt to this new food regime (GeorgescuRoegen 1977, p. 270). Less food and less number of human beings will probably imply less aggregate production. These features give credit to the usual link between bioeconomics and degrowth.

In his famous 1975 article, "Energy and Economic Myths", Georgescu-Roegen tackles the question of degrowth by exploring the argument of the steady-state defenders. According to him, these arguments do not lead to steady state, but to degrowth: the entropy law imposes constraints whatever the level of activity. If a certain level is sustainable today, it will not automatically be sustainable for a long time. A static solution is not a dynamic solution (Georgescu-Roegen 1975, p. 369). Unlike what this looks like, it would be inaccurate to consider this idea as a definitive call for degrowth. Georgescu-Roegen only evaluates the considerations of his fellow economists that defend the steady state. Degrowth would be the logical solution of the steady-state advocators, not his own.

Some lines further in the same 1975 article, he is more explicit about his own stance:

Undoubtedly, the current growth must cease, nay, be reversed. But anyone who believes that he can draw a blueprint for the ecological salvation of the human species does not understand the nature of evolution, or even history - which is that of a permanent struggle in continuously novel forms [...] (GeorgescuRoegen 1975, p. 369).

Here, Georgescu-Roegen clearly writes that growth should "cease, nay, be reversed". It is noteworthy that what is at stake is the reversal of "current growth", i.e. the reversal of industrial and material growth. This historical dimension is important: degrowth concerns some specific productions, in the context of a fossil-fuel energy regime. It does not consist in an ahistorical degrowth of aggregate production, measured by the GDP at all times. Nevertheless, this quotation may support a degrowth interpretation of bioeconomics, if degrowth is historically defined.

In one article published in French in 1982, Georgescu-Roegen seems to go further, putting aside his material specification of growth. Does he fully embrace degrowth here? It seems so (my translation):

Undoubtedly, the situation may radically change, without notice. But since nobody can be sure that Promethea III [a new technological shock, after fire with Pomethea I and the steam engine with Promethea II] will come, neither know exactly what will be his gift, one strategy must be implemented: a general and well planned conservation. In that way we will have more time to wait for the discovery of a new promethean gift, or, at least, to slide slowly and without dangerousness towards a less "warm" technology. Needless to say, this latter technology could only be a new wood era, somehow different from the previous one, because technical knowledge is wider today than before. [...] If this return becomes necessary, the profession of the economists will suffer a curious change: instead of being exclusively concerned by economic growth, the economists will look for optimal criteria to plan degrowth [la décroissance] (Georgescu- 


\section{Roegen 1982, p. 19).}

Here is probably the most explicit quotation from Georgescu-Roegen about degrowth. It explains why, at the end of his career, Georgescu-Roegen explicitly gave his support to some degrowth partisans (on that point, see Grinevald 1996). However, some questions remain about this radical claim. The 1982 paper was based on a conference presentation given in France at the beginning of the 1980s. The first version of the text was written by GeorgescuRoegen, and it was then corrected by Grinevald before publication (Georgescu-Roegen 1982, p. 24f). Since Grinevald was the one who chose the word "décroissance" to entitle GeorgescuRoegen's 1979 book, the new use of the word "décroissance" in that text raises questions. Of course, Grinevald did not distort GeorgescuRoegen's thinking; the bioeconomics' leader probably agreed with this word. Yet, at the time, in France, Georgescu-Roegen was already considered as a degrowth activist, because of his 1979 book. Using the "décroissance" concept once more was consistent, in the French language literature, with this reputation. But Georgescu-Roegen did not use the word "degrowth", which has been coined later. He episodically preferred "decline", which has not exactly the same meaning, being more qualitative than degrowth. At the very end of his life, in his English language literature, he still did not use this word. And the 1982 article seems to be a textual exception more than the rule.

Interpreting bioeconomics as a degrowth project finds some legitimacy in GeorgescuRoegen's own words, but this radical interpretation also rests upon questionable bases. Time has come to challenge it, and to show that it may not be the most accurate reading of bioeconomics.

\section{Bioeconomics without degrowth}

The common points between bioeconomics and a claim for a decrease of aggregate production concern some precise practices in consumption and production behaviours. When the bioeconomic programme is observed as a whole, a question must be raised: is this programme compatible with growth, or not? The question is voluntarily provocative, but it deserves interest. On a theoretical point of view, Miernyk (1999) shows that Georgescu-Roegen's production model is compatible with a certain kind of growth model, namely Leontief's inputoutput dynamic model. Of course, neoclassical growth models, as Solow's, are not consistent with the bioeconomic project. But the existence of a dynamic model (in which growth is possible) with the bioeconomic paradigm is a clue that boarders are not so clearly limited as it is usually presented.

On the same ground, Georgescu-Roegen himself does not reject growth in his economics of production. At the end of his fund-flow model account, he explains that growth is the result of the apparition of new processes and new organisations inside the economy. He admits that his model does not well report on such appearances. And he first regrets the inability of usual dynamic models to take into account these qualitative changes resulting in new ways of producing, consuming, and trading:

[...] I wish to submit that it is this $\prod$-sector [producing new processes] that constitutes the fountainhead of the growth and further growth which seems to come about as by magic in the developed economies and which, precisely for this reason, has intrigued economists and puzzled the planners of developing economies. By a now popular metaphor, we speak of the "take-off" of a developing economy as that moment when the economy has succeeded in creating within itself the motive-power of further growth. In light of the foregoing analysis, an economy can "take off" when and only when it has succeeded in developing a for us to recognize that the essence of development consists of the organizational and flexible power to create new processes rather than the power to produce commodities by materially crystallized plants. Ipso facto, we should revise our economics of economic development for the sake of our profession as a pure and practical art (Georgescu-Roegen 1971, p. 275).

This quotation testifies the manner Georgescu-Roegen conceives his bioeconomic project: it is a scientific project aiming at giving new foundations to economics, and it is a way to 
a better understanding of economic development. Growth is not a forbidden word, since it is the result of the emergence of new processes that could be accompanied with an increasing aggregate production.

On a more concrete level, the technical and regulation measures contained in the 1975 bioeconomic programme may have contrasted effects on economic growth. On the one side, it could weaken large parts of the industry; on the other side, it could reinforce new services (equipment repairs, short distribution channels) that could expand the economic sphere. The global effect of the bioeconomic programme on growth is unknown, with gains somewhere, and losses elsewhere (Söllner 1997, p. 183, Missemer 2013, p. 72). In the same way, looking for new viable techniques and new institutional frameworks will need investment in research and education. It will create wealth, and stimulate growth.

Is there any part of the bioeconomic project that could be inconsistent with degrowth, defined as the decrease of aggregate production measured by the GDP? There is no definitive answer to this question, but one may note that Georgescu-Roegen's urging on the development of a viable solar energy cannot be reached as fast as possible without new investments in research and development. These investments could come from the decline of other investments (for instance, in fossil fuels exploration), but if new financial supports were injected in these investments, would the result not be faster? Perhaps not, but it opens perspectives in the relationship between bioeconomics and creation of value. Since growth is considered as a wealth phenomenon, and not a mere material process, its compatibility with the bioeconomic project takes new features. Here stands the debate about the decoupling of economic growth from material consumption, which was not conceivable at Georgescu-Roegen's time, but which seems more conceivable today (FischerKowalski et al. 2011).

Coming back to the epistemological foundations of bioeconomics, GeorgescuRoegen's stance can hardly be considered as a claim for degrowth because of a radical difference between his perspective and the degrowth features. Defined as the decrease of aggregate production, degrowth remains, as growth, a quantitative idea. Bioeconomics consists in an opposite perspective, based on qualitative change and irreversibility. Georgescu-Roegen would have not accepted to encapsulate his whole project in a degrowth discourse, since degrowth remains mainly quantitative. $^{5}$

Moreover, degrowth is usually supposed to lead to steady state. After a first stage of decrease, aggregate production should maintain to a sustainable level to enable human life. Once more, such a trajectory is not compatible with Georgescu-Roegen's bioeconomics. Indeed, the steady state suffers from the criticisms Georgescu-Roegen addressed to Daly when this latter defended the stationary state in the 1970s:

Unlike what Kenneth Boulding and Herman Daly, with more strength, [...] advocate, ecological salvation cannot result from the stationary state. This idea seems to come from a logical mistake: a system that does not grow should be stable (Georgescu-Roe- gen 1978, p. 368).

Georgescu-Roegen's idea is to highlight that nothing except a Promethea III could free the human species from the consequences of the entropy law. If degrowth is conceived as a road to steady state with no change in the economic structures, it does not correspond to bioeconomics. In fact, bioeconomics and degrowth are paradigmatically different because they stand on different epistemological foundations. Degrowth defined as the decrease of aggregate production is a quantitative and mechanistic project. It runs into the epistemological basics of bioeconomics.

Georgescu-Roegen (1976) was particularly aware about the distinction between growth and development. This attachment may be explained by his narrow relations with François Perroux, one of the most important theoreticians of development (Røpke 2004, p. 303). His experience with Schumpeter participated also in

\footnotetext{
${ }^{5}$ Mainly but not totally because the increase or decrease of aggregate production may also result from qualitative changes (techniques of production, business organisation, etc.) - a way of reconciling some definitions of degrowth with bioeconomics.
} 
Georgescu-Roegen's awareness of this distinction between growth and development (Bobulescu 2012). While growth is a quantitative and mechanistic process, which measures only expansions and recessions in the level of economic activity, development is a more qualitative concept, inherited from biology. As a result, the notion of development is closer to bioeconomics than the notion of growth, and therefore than the notion of degrowth that is part of the same rhetorical category. What Georgescu-Roegen defended was a new kind of development. Degrowth was not his business.

\section{Conclusion: the "agrowth" option}

Nicholas Georgescu-Roegen is probably one of the most striking economists of the twentieth century. His bioeconomics fed a part of the young ecological debates of the 1970s and 1980 s, and his memory is still alive today. His supposed claim for degrowth is usually presented as obvious, but it raises questions. Some arguments support the degrowth interpretation of bioeconomics, but they cannot prevent other interpretations. Georgescu-Roegen has never clearly defended a general degrowth, defined as the decrease of aggregate production, except in one occasion, in a paper written in French for a readership expecting such a rhetoric. Bioeconomics constitutes a paradigmatic revolution, for economics and for economic practices. As a radical project, it arouses radical interpretations. But GeorgescuRoegen was also an economist who worked with Schumpeter, Leontief, and Samuelson. He wrote brilliant papers in the 1930 s about consumer preferences (see, for instance, GeorgescuRoegen 1936) and he wanted to articulate his first theoretical works with his later ecological concerns (Georgescu-Roegen 1966). As some recent works have shown (Røpke 2004, Bonaiuti 2011; Missemer 2013), his whole career is much more consistent that it is sometimes written (Maneschi and Zamagni 1997). GeorgescuRoegen was both a neoclassical and a heterodox economist, and that makes him a fascinating figure.

As regards degrowth, as shown in Section 4, Georgescu-Roegen was probably concerned neither with growth, nor with degrowth. He was concerned with qualitative change, with development. He admitted that the entropy law might lead to an economic decline. But decline is not degrowth, since it is more qualitative than merely quantitative. And decline was not his project. His project was the bioeconomic programme. Will this programme decrease the aggregate production? Perhaps, will it increase it? Perhaps, also, it does not matter. What matters is the implementation of cautious bioeconomic measures, whatever their effects on the GDP. In that sense, Georgescu-Roegen's project is closer to what Jeroen C. J. M. van den Bergh (2011) calls "agrowth", namely a mere disinterest about growth, with a focus on practical measures dealing with ecological constraints. Let us change society first, aggregate production will adapt in an unpredictable manner, but we should not care about it. Georgescu-Roegen's bioeconomics is on the same ground; it does not interest in quantitative aggregate production. It only deals with qualitative development, and its material bases.

Of course, Georgescu-Roegen laid the foundations for radical propositions to solve the ecological crisis, and, of course, he may rightly be a figure for inspiring the varied current degrowth movement. However, if degrowth is defined in its "most logical [...] and useful" sense (i.e. as the decrease of aggregate production), then Georgescu-Roegen cannot be considered himself as a full degrowth defender, since his bioeconomic project stands elsewhere, in a world in which growth is not a key concept.

\section{Acknowledgements}

I thank Ludovic Frobert who gave me the opportunity to go deeper in my understanding of Georgescu-Roegen; Véronique Dutraive, Christophe Salvat and the participants in the 2014 ESHET Conference for helpful comments on a former draft of this paper; and Philippe Quirion for inspiring discussions on the topic. Thanks also to the anonymous referees who have soundly oriented my inquiry. 


\section{References}

Ariès, P., 2010. La simplicité volontaire contre le mythe de l'abondance. Paris: La Découverte.

Bayon, D., Flipo, F., and Schneider, F., 2012. La décroissance. Dix questions pour comprendre et débattre. $2^{\text {nd }}$ ed. Paris: La Découverte.

Bobulescu, R., 2012. The making of a Schumpeterian economist: Nicholas GeorgescuRoegen. European journal of the history of economic thought, 19 (4), 625-51.

Bobulescu, R., 2013. L'expérience roumaine et son influence sur la pensée de Nicholas Georgescu-Roegen. Économies et sociétés, série $P E, 49,1753-75$.

Bobulescu, R., 2015. From Lotka's biophysics to Georgescu-Roegen's bioeconomics. Ecological economics, 120, 194-202.

Bonaiuti, M., 2011. From Bioeconomics to degrowth. Georgescu-Roegen's 'New Economics' in eight essays. London: Routledge.

Bonaiuti, M., 2012. Degrowth: tools for a complex analysis of the multidimensional crisis. Capitalism nature socialism, 23 (1), 30-50.

Bürgenmeier, B., 2008. Politiques économiques du développement durable. Brussels: De Boeck Université.

Cleveland, C. J. and Morris, C., 2014. Handbook of energy, vol. II. Chronologies, top ten lists, and word clouds. Waltham, MA: Elsevier Science.

Cleveland, C. J. and Ruth, M., 1997. When, where, and by how much do biophysical limits constrain the economic process? A survey of Nicholas Georgescu-Roegen's contribution to ecological economics. Ecological economics, 22 (3), 203-23.

Durand, F., 2008. La décroissance: rejet ou projet? Paris: Ellipses.

Farrell, K. N. and Mayumi, K., 2009. Time horizons and electricity futures: an application of Nicholas Georgescu-Roegen's general theory of economic production. Energy, 34 (3), 301-07.

Fischer-Kowalski, M., et al., 2011. Decoupling natural resource use and environmental impacts from economic growth. Technical report. New York: United Nations Working Group on Decoupling.

Fisk, D., 2011. Thermodynamics on main street: when entropy really counts in economics. Ecological economics, 70 (11), 1931-6.

Georgescu-Roegen, N., 1936. The pure theory of consumer's behaviour. Quarterly journal of economics, 50 (4), 545-93.

Georgescu-Roegen, N., 1966. Analytical economics. Issues and problems. Cambridge, MA: Harvard University Press.

Georgescu-Roegen, N., 1971 [ed. 1999]. The entropy law and the economic process. Cambridge, MA: Harvard University Press.

Georgescu-Roegen, N., 1975. Energy and economic myths. Southern economic journal, 41 (3), 347-81. From a 1972 oral presentation.

Georgescu-Roegen, N., 1976. Energy and economic myths. Institutional and analytical economic essays. New York: Pergamon Press.

Georgescu-Roegen, N., 1977. The steady state and ecological salvation: a thermodynamic analysis. BioScience, 27 (4), 266-70.

Georgescu-Roegen, N., 1978. De la science économique à la bioéconomie. Revue d'économie politique, 88 (3), 337-82.

Georgescu-Roegen, N., 1982. La dégradation entropique et la destinée prométhéenne de la technologie humaine. Économie appliquée, XXXV (1-2), 1-26.

Georgescu-Roegen, N., 1983/2011. Bioeconomics and ethics. In: M. Bonaiuti, ed. From bioeconomics to degrowth. GeorgescuRoegen' $s$ 'New Economics' in eight essays. London: Routledge, 142-5.

Georgescu-Roegen, N., 1984. Feasible recipes versus viable technologies. Atlantic economic journal, 12, 21-31.

Georgescu-Roegen, N., 1989/2011. Quo vadis Homo sapiens sapiens? In: M. Bonaiuti, ed. From bioeconomics to degrowth. GeorgescuRoegen' $s$ 'New Economics' in eight essays. London: Routledge. 158-70. 
Georgescu-Roegen, N., 1993. Thermodynamics and we, the humans. In: J. C. Dragan, E. K. Seifert, and M. C. Demetrescu, eds. Economics and bioeconomics. Milan: European Association for Bioeconomic Studies, 184-201.

Georgescu-Roegen, N., 2006. La décroissance. Entropie, écologie, économie. Paris: Éditions Sang de la terre.

Grinevald, J., 1990. Vernadsky y Lotka como fuentes de la bioeconomia de GeorgescuRoegen. Ecologia politica, 1, 99-122.

Grinevald, J., 1992. La révolution bioéconomique de Nicholas Georgescu-Roegen. Stratégies énergétiques, biosphère et société, october, 23-34.

Grinevald, J., 1996. Prologo. In: La Ley de la Entropia y el Proceso Economico, 15-40. Madrid: Fundacion Argentaria/Visor. Spanish Translation of The Entropy Law and the Economic Process, by J. M. Naredo.

Grinevald, J., 2007. La biosphère de l'anthropocène. Climat et pétrole, la double menace. Repères transdisciplinaires (18242007). Geneva: Georg Éditeur.

Grinevald, J., 2008. Introduction to GeorgescuRoegen and degrowth. In: F. Flipo and F. Schneider, eds. Proceedings of the first international conference on economic de-growth for ecological sustainability and social equity, 18-19 April 2008, Paris, 14-7.

Herrmann-Pillath, C., 2011. The evolutionary approach to entropy: reconciling GeorgescuRoegen's natural philosophy with the maximum entropy framework. Ecological economics, 70 (4), 606-16.

Kallis, G., Kerschner, C., and Martinez-Alier, J., 2012. The economics of degrowth. Ecological economics, 84, 172-80.

Kurz, H. D. and Salvadori, N., 2003. Fund-flow versus flow-flow in production theory: reflections on Georgescu-Roegen's contribution. Journal of economic behavior \& organization, 51 (4), 487-505.

Levallois, C., 2010. Can de-growth be considered a policy option? A historical note on Nicholas Georgescu-Roegen and the Club of
Rome. Ecological economics, 69, 2271-8.

Maneschi, A. and Zamagni, S., 1997. Nicholas Georgesu-Roegen, 1906-1994. Economic journal, 107 (442), 695-707.

Miernyk, W.H., 1999. Economic growth theory and the Georgescu-Roegen paradigm. In: K. Mayumi and J. M. Gowdy, eds. Bioeconomics and sustainability. Essays in honor of Nicholas Georgescu-Roegen. Cheltenham: Edward Elgar, 69-81.

Missemer, A., 2013. Nicholas GeorgescuRoegen, pour une révolution bioéconomique. Lyon: ENS Éditions.

Paris Décroissance, 2008. Final declaration. In: F. Flipo and F. Schneider, eds. Proceedings of the first international conference on economic de-growth for ecological sustainability and social equity, 18-19 April 2008, Paris, 317-8.

Petit, R., 1997. L'économie écologique, une économie politique alternative? Thesis $(\mathrm{PhD})$. Université Lille 1.

Røpke, I., 2004. The early history of modern ecological economics. Ecological economics, 50, 293-314.

Söllner, F., 1997. A reexamination of the role of thermodynamics for environmental economics. Ecological economics, 22 (3), 175-201.

van den Bergh, J. C. J. M., 2011. Environment versus growth - a criticism of "Degrowth" and a plea for "A-growth". Ecological economics, 70, 881-90.

Vittucci Marzetti, G., 2013. The fund-flow approach: a critical survey. Journal of economic surveys, 27 (2), 209-33.

Vivien, F.-D., 1994. Économie et écologie. Paris: Repères La Découverte.

Vivien, F.-D., 2005a. Le développement soutenable. Paris: Repères La Découverte.

Vivien, F.-D., 2005b. Le développement soutenable: un sujet controverse chez les économistes. Desenvolvimento e meio ambiente, 11-12, 85-94. 